\title{
Merze Tate and the Quest for Gender Equity at Howard University: 1942-1977
}

\section{Linda M. Perkins}

This study discusses Merze Tate, a black woman faculty member at Howard University from 1942 to 1977 , and her efforts throughout her tenure at the institution to obtain gender equity for women faculty. This study also discusses Tate's decades-long battle with Rayford Logan, chair of the history department of Howard. Both Harvard PhDs, their difficulties reflect both gender differences as well as professional jealously. Tate was the first black woman to earn a degree from Oxford University (International Relations, 1935) and the first black woman to earn a $\mathrm{PhD}$ from Harvard in the fields of government and international relations (1941). She joined the faculty at Howard University in 1942 , as one of two women ever hired in the history department. She remained on the faculty until her retirement in 1977. Tate is significant not only for her academic accomplishments and her advocacy on behalf of women but also as one of the earliest tenured women faculty members at Howard. In addition, she was a part of a very small group of highly accomplished black women academics who devoted their lives to the education of black youth. In a 1946 study of black doctorate and professional degree holders, Harry Washington Greene noted that of the three hundred eighty-one recipients, only forty-five were women. Black women were overwhelmingly enrolled and graduated from teacher training colleges that were unaccredited and/or did not provide the curriculum to attend graduate school without taking an additional year of undergraduate studies. The time and cost factor were prohibitive and many black women attended summer schools for years to take courses to prepare them for a graduate degree program. ${ }^{1}$

Linda M. Perkins is an Associate University Professor and Director of Applied Women's Studies and Africana Studies Certificate Program, Claremont Graduate University, Claremont, California; e-mail: Linda.perkins@cgu.edu. I would like to acknowledge the archival assistance of Clifford Muse Jr., University Archivist at Howard University Archives, and Ida E. Jones, Assistant Curator of the Moorland-Spingarn Research Center at Howard University. I would also like to acknowledge the editorial assistance of Tiffani Smith, doctoral student at Claremont Graduate University. The research for this article was supported by a grant from the Spencer Foundation.

${ }^{1}$ Harry W. Greene, Holders of Doctorates among American Negroes (Boston, MA: Meador Press, 1946). 


\section{Merze Tate}

Tate was born in 1905 in western Michigan in the small town of Blanchard where her great-grandparents as free blacks migrated to in the mid-nineteenth century from Ohio. Little is known about her family other than she had four siblings, which included one brother, two halfbrothers, and one half-sister. It is unknown where Tate was in the birth order. Her family correspondence includes letters to her mother, her siblings, nieces, and nephews and reflects a lifelong, close relationship with them. Tate excelled as a student and graduated valedictorian of her high school at Blanchard High in 1924. Receiving a tuition scholarship, Tate enrolled and earned her BA in three years from Western State Teachers College in 1927 in Michigan. Graduating with honors, Tate became the first black to graduate from the institution. With her teaching credentials and barred from teaching in Michigan because of her race, from 1928 to 1931 Tate was employed as a public high school teacher at the Crispus Attucks High School in Indianapolis, Indiana. As was the case with other black women who graduated from teacher training programs, Tate took extension courses from Indiana University in French, German, and European History during the period of her high school teaching. Also, for three summers (1928-1930), she attended Teachers College at Columbia University and earned a master's degree in Social Science Education in 1930. Her thesis was entitled, "Reorganization of Social Science Curricula for Secondary Schools." Tate wanted to prepare herself to be one of the top scholars in her field-European and diplomatic history and international relations. ${ }^{2}$

With the requisite preparation for further study, in 1931 Tate was awarded a fellowship for international study from Alpha Kappa Alpha (AKA); the oldest African American sorority that was founded at Howard University in 1908 and of which Tate was a member. Tate chose Oxford University. In her fellowship report to AKA, Tate noted that one year of study would not have covered the courses that she desired in international relations, a program which required two to five years. She wanted to earn the B. Litt degree, which she said was the equivalent of the French doctorate or the American PhD. Although she had no funds beyond one year, as she demonstrated throughout her life, Tate relied on her intellect and her persuasive abilities. The summer prior to entering Oxford, Tate obtained a certificate from the Geneva School of International Studies in 1931. She noted that she had been one of sixteen students of two hundred twenty-eight applicants to

${ }^{2}$ Application for Foreign Fellowship for Alpha Kappa Alpha Sorority, 1931, Vernie Tate Papers, box 219-1, folder 20, Manuscript Division, Moorland-Spingarn Research Center, Howard University, Washington, DC, hereafter referred to as the Tate Papers. 
participate in a select presidential seminar at Geneva. ${ }^{3}$ The head of the summer program in Geneva was Alfred E. Zimmern, a distinguished scholar and Oxford professor. Impressed with Tate's academic performance with him in the Geneva summer program, Zimmern agreed to work with Tate during her stay at Oxford. She noted, "I never dreamt of being privileged to sit under his individual and personal instruction in Oxford, he is an outstanding figure." ${ }^{4}$ Fortunately for Tate, Zimmern spent part of her first year at Oxford lecturing in the United States. While he was in the States, he was able to secure a fellowship from the Phelps Stokes Foundation for her to continue her studies at Oxford. This fellowship, along with a scholarship from the Home Students grant at Oxford, a gift from an anonymous Oxonian, additional loans from an Oxford fund and from her sister, she was able to complete her studies. While at Oxford, in addition to work with Zimmern in International Relations, she also studied International Law with, J. L. Brierly, a renowned Oxford professor and jurist of the World Court. Tate also studied economics, history, and geography at Oxford. Completing her years in England, Tate noted, "throughout the three years I spent in England, I was ever conscious of being a pioneer representing AKA in particular and Negro womanhood in general. The latter fact was impressed upon me by the circumstance that I was the first Colored American women to matriculate at Oxford and, as far as I know the first colored American to receive a higher degree from the University." "Tate earned the B. Litt. from Oxford in 1935. She stated she wanted to attend a German university before she returned to the United States and the summer after she graduated from Oxford, she studied at the University of Berlin. Tate was determined to obtain the highest qualifications in her field so that she could compete without questions from anyone. ${ }^{6}$

Returning to the States in the middle of the Depression, Tate took the only position she could secure, one as Dean of Women and teacher of history at Barber-Scotia Junior College for Females, in Concord, North Carolina, a small private college founded by Presbyterians. While this position was welcomed at Barber-Scotia, it was a huge disappointment for Tate. Dean of Women's positions were growing as a position in historically black colleges or universities (HBCUs). ${ }^{7}$ The

\footnotetext{
${ }^{3}$ Merze Tate, "Three Years in England," Ivy Leaf Magazine 14, no. 1 (March 1936): $18-19,40$.

${ }^{4}$ Ibid., 18.

${ }^{5}$ Ibid., 40.

${ }^{6}$ Ibid., 40.

${ }^{7}$ For more information on the dean of women's position in HBCUs see Linda M. Perkins, "The National Association of College Women: Vanguard of Black Women's
} 
Dean of Women's position at HBCUs was primarily a position of policing women's moral conduct and maintaining discipline while Tate was a scholar interested in scholarship and teaching. The following year, she moved to Bennett College, another private denominational all female college founded by the Methodist Church. In this position, Tate served as Chair of the Division of Social Science until 1941. This position was a stepping-stone to greater ambitions. In 1939, Tate obtained a fellowship from the Julius Rosenwald Foundation for support of her doctorate from Harvard University in Government and International Relations, which she earned in 1941. Her dissertation, "The Movement for a Limitation of Armaments to 1907," was an extension of the research project at Oxford and became her first book. Desiring to work at the top University available to black faculty, Tate set her sights on teaching at Howard University. ${ }^{8}$

As she sought to build her professional career, Tate noted that race and gender were going to be obstacles in her life. On her application in 1939 to the Rosenwald Foundation for support of her doctoral studies at Harvard, on the line that asked applicants if they had any disabilities, Tate wrote: colored woman. ${ }^{9}$

Exploring the experiences of black women faculty at Howard is important because it was the most prestigious HBCU of the period being examined and attracted the leading black scholars of the era. Howard was founded in 1867 by the Freedman's Bureau and with funding from the United States Congress. While most black colleges were primarily of high school grade, by 1925 Howard enrolled over two thousand college-level students with more than 150 professors. It was the preeminent black university that boasted ten schools and colleges (including medicine, dental, pharmacy, divinity, law, and social work) that were fully accredited during the presidency of the first black president, Mordecai W. Johnson (1926-1960). ${ }^{10}$ As a result of Howard's unique funding source (the federal government), it was unlike the overwhelmingly private black colleges that were founded by white missionaries or black church denominations and dependent upon donations. In addition, the black land-grant colleges were established in 1890 from the

Leadership and Education, 1923-1954," Fournal of Education 172, no. 3 (1990): 65-75; Caroll L. Miller and Anne S. Pruitt-Logan's, Faithful to the Task at Hand: The Life of Lucy Diggs Slowe (New York: SUNY Press, 2012). Slowe was the first black women Dean of Women at Howard University. Her tenure as Dean was from 1922 to 1937.

${ }^{8}$ Biographical Materials and CV, Tates Papers, box 219-1, folder 3, Manuscript Division, Moorland-Spingarn Research Center, Howard University, Washington, DC.

${ }^{9}$ Merze Tate's Application to the Julius Rosenwald Fund, March 31, 1939, Julius Rosenwald Papers, box 451, folder 4 (1939-1943), Fisk University Archives, Fisk University, Nashville, Tennessee.

${ }^{10}$ Rayford W. Logan, Howard University: The First Hundred Years, 1867-1967 (New York: New York University Press, 1969). 
Second Morrill Act that provided funding to establish separate state colleges in seventeen southern and border states. ${ }^{11}$ In 1928, Howard amended its charter to authorize annual federal appropriations for construction, development, improvement, instruction, and maintenance of the University. Hence, unlike other HBCUs, Howard's existence and finances were secure. ${ }^{12}$ It was also the top HBCU that produced students prepared to do graduate study. In Greene's study of African Americans with doctorates, he noted that of the 343 recipients, forty-eight had attended Howard as undergraduates while only sixteen had attended Fisk University. The other top HBCUs that were the undergraduate origins of black doctorate recipients were Lincoln University (PA), which had eighteen graduates, and Virginia Union and Morehouse Colleges, which both graduated sixteen students to obtain doctorates. All of the top five HBCUs that produced the largest number of doctoral students, with the exception of Howard, were those established for men. Black women were overwhelmingly located in teacher training programs and institutions that required additional preparation for advanced graduate study. ${ }^{13}$ The women faculty at Howard with doctorates and professional degrees reflect the data of Greene's study in their undergraduate origins. They were graduates of white undergraduate institutions or Howard. Black women who attended non-HBCUs or Howard had a significant advantage in obtaining admissions to graduate and professional schools. ${ }^{14}$

While the prevailing literature on women's higher education chronicles the profound difficulty white women experienced in obtaining academic appointments due to sexism, nepotism, or custom, black colleges readily employed black women academics. ${ }^{15}$ This study also addresses the intersectionality of race and gender as experienced in black women's professional lives at Howard. Numerous contemporary black feminists, such as Kimberle Crenshaw and Patricia Hill Collins, built on the voices of nineteenth and early twentieth century black feminist theorists and wrote of the challenges and treatment of black women who spent their lives negotiating both race and gender in spaces that

${ }^{11}$ Morrill Act of 1862 (7 U.S.C. $\$ 301$ et seq.) and the Morrill Act of 1890 (the Agricultural College Act of 1890 (26 Stat. 417, 7 U.S.C. \$ 321 et seq.).

${ }^{12}$ Logan, First Hundred Years, 258.

${ }^{13}$ Greene, Negro Holders of Doctorates, 37.

${ }^{14}$ On this topic see Linda Perkins' "The History of Black Women Graduate Students, 1921-1948" in The Sage Handbook on African American Education, ed. Linda C. Tillman (Chapel Hill, NC: University of North Carolina Press, 2009), 53-65.

${ }^{15}$ Barbara Solomon's book, In the Company of Educated Women: A History of Women's Higher Education (New Haven, CT: Yale University Press, 1985) devotes an entire chapter to this dilemma, see chapter eight. Also see Joyce Antler's "After College, What?': New Graduates and the Family Claim," American Quarterly 32 (Fall, 1980): 409-34. 
are predominately male or predominately white and the notion of the intersectionality of these issues. ${ }^{16}$ At Howard, while their work setting was African American, their superiors were men. Howard University was in the vanguard of research and activities to advance the causes of blacks and to expose racial discrimination. However, these issues were primarily male focused and male lead. The experiences of black women faculty at the elite university of predominately black male faculty and administrators present a classic case study on race and gender. While it is well known that black women have served on the faculties of HBCU's, even the all-male Morehouse College employed black women faculty. However, what is less known are the experiences and treatment of black women on these campuses. ${ }^{17}$

Howard was in many ways an outlier in black higher education because it had established faculty ranks, a tenure system, and a pension system which no other black college had. Thus, it was the first choice for black academics. Because of these reasons, Rayford Logan in history and Frank Snowden in classics, both Harvard PhDs, left Atlanta University in 1938 to join the faculty of Howard. ${ }^{18}$

Even Fisk University, the small liberal arts college in Nashville and the most distinguished of its group could not attract top black faculty early on in the twentieth century for this reason. For example, in 1944, the well-known writer, Countee Cullen, turned down a faculty position at the college, because of the absence of a retirement plan. In his gracious letter declining the offer, he wrote:

In order to be perfectly frank with you, I feel I should mention another reason for my inability to accept your offer, namely the fact that Fisk has

${ }^{16}$ Patricia Hill Collins, Black Feminist Thought: Knowledge, Consciousness, and the Politics of Empowerment (London: Routledge, 1999); Kimberly Crenshaw, "Intersectionality: The Double Bind of Race and Gender," Perspectives Magazine (2004): 4-7.

${ }^{17}$ In HBCUs where African Americans served on their faculty, black women were readily hired. Mary Church (later Terrell), one of the earliest black women graduates of Oberlin College (1884), accepted a teaching position at Wilberforce College in Ohio in 1885 , which was founded by the African Episcopal Church prior to the Civil War (1856). Terrell recalled that she received numerous offers from Black colleges mostly in the Deep South. She decided on Wilberforce because of its location in Ohio. She noted that college educated black women were in great demand, noting, "The heads of institutions for colored youth were beginning to insist that the teachers employed should be college graduates, and there were so few colored women who met this requirement then that it was very easy for those who had to secure desirable positions." Quote found in Mary Church Terrell, $A$ Colored Woman in a White World (Amherst, NY: Humanity Books, 1968), 61.

${ }^{18}$ Annual Report of the College of Liberal Arts, 1938, Howard University, MoorlandSpingarn Library and Kenneth Robert Janken, Rayford W. Logan and the Dilemma of the African-American Intellectual (Amherst: University of Massachusetts Press, 1993), vii-319. 
no pension fund. If I were a younger man or an unmarried man, such a consideration could be discounted, but I am neither of these, and the matter of pension has naturally played a large part in the discussion between my wife and me. ${ }^{19}$

Religious scholar and later president of Morehouse College, Benjamin E. Mays (1940-1967) communicated with Fisk University about a faculty position while he was a doctoral student at the University of Chicago in 1933. Mays was offered a position at Fisk in 1934 at a salary of $\$ 3,000$. Mays was disappointed with the salary and said his previous two positions paid $\$ 4,000$ and $\$ 3,375$ working at the Institute for the Social Religious Research and YMCA in Atlanta, respectively. He also indicated that his wife Sadie earned $\$ 2,400$, a salary that would be lost if they came to Fisk because Thomas Jones, president of Fisk at the time, indicated that the college had a policy of not hiring spouses (which actually meant not hiring wives). Mays indicated his wife could look for work within Nashville. Jones replied that the salary was firm and may have to be reduced by 15 percent due to the Depression and serious financial problems of the College. Mays accepted the offer on March 18, 1934. Less than a month later, Mays discovered that he had an opportunity for a position at Howard and asked President Jones to release him from his acceptance to come to Fisk. After President Jones released Mays from his acceptance letter, Mays became the Dean of Howard's School of Religion and his wife Sadie was hired to teach in Howard's School of Social Work. Howard was able to trump all HBCUs in salary and positions. ${ }^{20}$ While Fisk was accredited and of college level, it was a small college founded by the American Missionary Association and constantly had to appeal for funds. Howard remained the most competitive HBCU for employment for black academics.

Numerous studies in the decades of the 1920s, 1930s, and 1940s discuss the challenges and issues of HBCUs. The institutions varied in types and funding. In a study of the seventy-nine black colleges that existed in 1928, they were classified as independent (twenty-eight), land grant (sixteen), teaching training (eleven), white denominational church

${ }^{19}$ Countee Cullen to Dr. Thomas E. Jones, President of Fisk University, August 24, 1944, Thomas E. Jones Papers, box 50, folder number 21, Fisk University Archives, Fisk University, Nashville, Tennessee.

${ }^{20}$ Benjamin E. Mays to Thomas E. Jones, president of Fisk University, November 26, 1933; Benjamin E. Mays to Thomas E. Jones, February 20, 1934; Benjamin E. Mays to Thomas E. Jones, March 4, 1934; Benjamin E. Mays to Thomas E. Jones, March 18, 1934; box 52, folder 22, Thomas Jones Papers; Western Union telegram from B. E. Mays to President Thomas E. Jones, Fisk University, April 11, 1934; B. E. Mays to President Thomas E. Jones, April 10, 1934; Thomas E. Jones to B. E. Mays, April 14, 1934; B. E. Mays to Thomas E. Jones, April 17, 1934, box 52, folder 22, in Tbomas E. Fones Papers, Fisk University, Fisk University Archives, Nashville, Tennessee, hereafter referred to as the Fones Papers. 
founded (ten), and black denominational church founded (nine). Among these institutions, 86 percent of the faculty had at least one degree and the rest none. Thirty-four percent of the faculty had graduate degrees. ${ }^{21}$ As noted above with the examples of Cullen and Mays, reports in 1933 and in 1946 noted the lack of tenure, year-to-year appointments, no retirement plans, rapid faculty turnover (a third to a half of the faculty turned over in a three-year period), and small salaries often with no salary scale with salaries being negotiated with the president. ${ }^{22} \mathrm{~A}$ study in 1933 that observed the ten liberal arts colleges that had " $A$ " classifications with the Southern Accreditation Association, of the 220 faculty members surveyed, noted that one-third had only bachelor's degrees and less than one-tenth had doctorates. ${ }^{23}$

While the names of prominent black male scholars, such as the first Black Rhodes scholar Alain Locke, Sterling Brown, John Hope Franklin, Benjamin Mays, Howard Thurman, Ernest Just, E. Franklin Frazier, Rayford Logan, Ralph Bunche, Frank Snowden, Charles Hamilton Houston, who taught at Howard, are well known, little is known of the equally impressive list of black women faculty members who joined the faculty immediately after Mordecai Johnson became president in 1926.

Two studies of the most prominent black male faculty members at Howard have been published. The first is Confronting the Veil: Abram Harris, Fr., E. Franklin Frazier and Ralph Bunche, 1919-1941 by Jonathan Scott Holloway, who discusses the struggles these male scholars were confronted with in being "Black intellectuals." In addition, Zachery R. Williams' study, In Search of the Talented Tenth: Howard University Public Intellectuals and the Dilemmas of Race, 1926-1970, discusses the "Big Six," Abram Harris Jr., E. Franklin Frazier, Rayford Logan, Ralph Bunche, Alain Locke, and Sterling Brown, as the leading forces at Howard. ${ }^{24}$

${ }^{21}$ Arthur J. Klein, "Survey of Negro Colleges and Universities," Bulletin of the Bureau of Education of the Department of the Interior, no. 7 (1928): 1-956, box number 52, 23, Jones Papers.

${ }^{22}$ Lloyd E. Blauch and Martin D. Jenkins, Intensive Study of Selected Colleges for Negroes. National Survey of the Higher Education of Negroes, Miscellaneous, 1942, II, number 6, United States Office of Education; Charles S. Johnson, "The Faculty," Zournal of Educational Sociology 19, no. 8 (April 1946): 471-83.

${ }^{23}$ Charles S. Thompson quoted in Louis Ray, "Competing Visions of Higher Education: The College of Liberal Arts Faculty and the Administration of Howard University, 1939-1960," in Higher Education for African American before the Civil Rights Era, 1900-1964, Perspectives on the History of Higher Education 29, eds. Marybeth Gasman and Roger L. Geiger (New Brunswick, NJ: Transaction Publishers, 2012), 153; Tenure and rank guidelines were completed at Howard in 1938, see 1938-1939 Annual Report of the College of Liberal Arts.

${ }^{24}$ See Jonathan Scott Holloway, Confronting the Veil: Abram Harris, Jr., E. Franklin Frazier, Ralph Bunche, 1919-1941 (Chapel Hill: University of North Carolina, 2001); and Zachery R. Williams, In Search of the Talented Tentb: Howard 
All of these men were Merze Tate's colleagues throughout her years at Howard. Although Tate was by no means a member of the "Big Six," she, along with other prominent black women faculty, challenged the administration regarding faculty women's equity issues in salary and promotion starting in the late 1940s. Tate's tenure at Howard was one of a constant battle with Rayford Logan, the chair of the history department and one of the "Big Six." Logan, like Tate, also held a doctorate from Harvard University. In her battle for salary equity, Tate never hesitated to point out to Logan that her credentials were the same as his.

\section{Black Women Faculty at Howard}

Black women faculty at Howard was a "Who's Who" of the most educated black women of their era. Unlike many of the distinguished black male faculty who left for other posts during their careers as academics, black women faculty remained at Howard their entire professional career. ${ }^{25}$ Institutional and personal papers in the Moorland-Spingarn Research Center at Howard University provide four decades of history of women faculty and administrators. Three black women earned PhDs in 1921, which were the first for the race. All three were offered faculty positions at Howard. Two of the women accepted. Eva Dykes, who earned her doctorate in English Philology from Radcliffe, and Georgiana Simpson, who earned a doctorate in Germanic languages from the University of Chicago, joined the faculty. Sadie Tanner

University Public Intellectuals and the Dilemmas of Race, 1926-1970 (Columbia: University of Missouri Press, 2009).

${ }^{25}$ Abrah Harris, Ernest Just, Ralph Bunche, Howard Thurman, John Hope Franklin, and Benjamin E. Mays are some of the noted scholars who left Howard for better professional opportunities. Only Eva Dykes, who left Howard for religious reasons (to help build up the black Seventh Adventist Oakwood College), is the only tenured black woman faculty member to leave. However, women faculty at HBCUs frequently relocated to other institutions for a better salary and rank. This was indeed the case with Tate when she left Barber-Scotia after five years to join the faculty of Bennett College and left the following year to become Dean of Women at Morgan State College in Baltimore (1941) and left the following year to join the faculty of Howard (1942) where she stayed the remainder of her professional career (Tate Papers, box 219-2). Also, Flemmie Kittrell, after graduating from Hampton Institute (VA) with a bachelor's of science in Home Economics in 1924. She served for twelve years as Dean of Women at Bennett College during which time she earned a masters and doctoral degree from Cornell University (1935) in Home Economics with a specialty in Nutrition. Kittrell returned to Hampton in 1940 and served as Dean of Women until 1944. She went to Howard in 1944, two years after Tate where she became Chair of the Department of Home Economics and the founding Dean of the School of Home Economics. Like Tate, Kittrell remained at Howard the rest of her career when she retired in 1973, See Flemmie Kittrell's Oral History, Women of Courage, Schlesinger Library, Radcliffe College, Cambridge, MA. August, 29, 1977. 
Alexander who earned a doctorate in economics did not become an academic and declined the offer. ${ }^{26}$

As a small but steady number of black women earned graduate and professional degrees, Mordecai Johnson, the first black president of Howard (1926), recruited them to the faculty. Dorothy Ferebee was the first black woman to graduate from Tufts Medical School in 1924. She joined the Howard Medical School faculty in 1930 and remained until her retirement in 1968. Dorothy Porter Wesley was a 1928 alumna of Howard and was the first black woman to earn a masters in Library Science from Columbia University (1932). She was appointed to the staff of Howard in 1932 to establish the special collection and worked in the Moorland-Spingarm Collection. She remained at Howard until her retirement in 1975. Inabel Lindsay was a 1920 alumna of Howard University. She earned a masters in Social Work from the University of Chicago in 1937 and returned to Howard to join the faculty in that same year. In 1945, Lindsay became the first Dean of the School of Social Work at Howard, a position she held until her retirement in 1968. Flemmie Kittrell was the first black woman to earn a $\mathrm{PhD}$ in the field of Nutrition (Cornell 1938). In 1944, she joined the faculty of Howard University to establish and become Dean of the first School of Home Economics. Like Ferebee, Kittrell's work took her beyond the campus and into rural towns and developing countries of the world to work on issues of nutrition. She served as Dean until her retirement in $1972 . .^{27}$

There were many other women who were on the faculty and some who emerged as heads of departments during their tenure at Howard particularly in the beginning of the 1970s. The recent release of the Merze Tate Papers at Moorland-Spingarn has provided eye opening revelations of her importance to gender equity at Howard and to black women in higher education in general. The Merze Tate Papers also reveal the critical dynamic of gender in a predominately African-American institution. As noted earlier, leading black feminist theorists have provided significant literature on this topic. While highly educated black women were needed on black campuses everywhere, their presence was necessary for accreditation purposes and to provide the necessary instruction and care to the students and institution. There was little difficulty for women obtaining positions at HBCUs, their issues reflected more around compensation, rank, and not being hired.

${ }^{26}$ Eva Dykes, Oral Interview, Women of Courage, Radcliffe College, Interview with Sadie Tanner Mossel Alexander, October 12, 1977 in Alexander Family Papers, University of Pennsylvania Archives, Philadelphia, PA.

${ }^{27}$ See Flemmie Kittrell Papers, Manuscript Division, Moorland-Spingarn Research Center, Howard University, Washington, DC. 


\section{Howard University}

Tate was hired at Howard in 1942 during the war years as a temporary faculty member. In the Rayford Logan's Papers and diaries, he notes his decision to hire Tate. Logan was appointed Interim Dean for that year. He wrote that there was a white woman candidate who also had a doctorate from Harvard, Caroline Ware, who lived in Virginia and was a more mature scholar and whom he described as "less of a personality problem than Tate." Nevertheless, he noted that Tate was colored and he was "more inclined towards Tate." In the end, both women were hired, becoming the first women faculty in the history department at Howard. ${ }^{28}$ Logan's diary entry also indicated he met with Charles Wesley, the head of the history department, for more than three hours and said Wesley also agreed that Tate was preferable to Ware. He recommended Tate for the contingent position in the history department. ${ }^{29}$

By the following July, neither Tate nor Ware had been informed whether they would be reappointed. Logan's diary noted that Tate needed to know her reappointment status immediately because she had a job offer in Detroit. He indicated that since his position as Interim Dean of Liberal Arts had been extended through the end of December, he could use his salary to keep Tate on through the first quarter and she agreed to that arrangement. ${ }^{30}$ In 1945 , with the war ending, Tate sought a more permanent position at Howard University.

After discovering a faculty opening in Geography and Geopolitics at Howard, Tate applied for the position. In a two-and-a-half-page letter of application to the J. St. Clair Price, Dean of the College of Liberal Arts, Tate stated that she researched the teaching of geography at the local institutions. She soon discovered that Catholic University offered no courses in that field, that American University only offered these course in the social sciences and that George Washington University offered three geography courses and a geopolitics course in the Political Science department. Tate told Dean St. Clair Price that such courses are offered as social sciences. Tate explained that while her degrees were not in geography, "I feel that I need offer no apology for my preparation or for my teaching experience in that field." She stated that while in college, she took every geography course offered to supplement her study of history, economics, sociology, and government. She listed nine geography courses she had taken (from the introductory, advanced, economic geography, geography of south America, geography

${ }^{28}$ Diary entry, September 3, 1942, Rayford Logan Papers, box 3, folder 7, Library of Congress, Washington, DC.

${ }^{29}$ Diary entries 7, September 11, 1942, Logan Papers.

${ }^{30}$ Diary Entry, July 17, 1943, Logan Papers, box 4, folder 2. 
of Mexico and the Caribbean, Geography of Europe and Asia, historical geography, reconstruction of Europe, and her practice teaching was in the field of geography). She stated she earned the grade of an "A" in each of these courses (she attached her transcript). Tate also noted that she had taught geography for nine years-eight at the college level at Bennett College and at Barber-Scotia College. Most importantly she had taught the topics for two years at Howard. ${ }^{31}$

Tate stated in addition to her academic qualifications, she had traveled to thirty-eight of the then forty-eight states. Tate had traveled to Mexico, across Canada, and had lived and traveled throughout western Europe for three years and a summer. Tate stated travel was important to a professor of geography. Tate noted that she had two publications in the process on geopolitics. Tate submitted a course of study for geography and wrote:

I should be willing to accept a temporary appointment as Professor of Geography until you have had time to survey further the situation. Moreover, if during the first year of the establishment of a full-time geography department the enrollment should not require all [of] my time, I should be pleased to assist in either the History of the Political Science Departments or to carry one Social Science Survey course. Knowing the general situation at Howard University, I doubt if we would be able to offer profitably more than twice the number of courses available at George Washington and American universities. Herewith is submitted a proposed course of study in geography for $1945-46 .^{32}$

In Tate's last paragraph, she made it infinitely clear that there could be no better candidate for the position. She wrote:

if, after considering all [of] the above qualifications, you are able to secure someone who has had more subject matter courses in both geography and the social sciences - the latter very necessary for the teaching of geography' a person had has had more than sixteen years of general teaching and administrative experience, nine of which have been in the field of geography; a person who has traveled at home and abroad more extensively; a person who has published two studies in either the field of geography or international

${ }^{31}$ Merze Tate to J. St. Clair Price, Dean of Liberal Arts, Howard University, July 17, 1945, Merze Tate Papers, box 219-5, folder 29, Manuscript Division, MoorlandSpingarn Research Center, Howard University, Washington, DC.

${ }_{22}$ Merze Tate to J. St. Clair Price, Dean of Liberal Arts, Howard University, July 17,1945 , Tate Papers; Tate was well versed in a variety of fields. While her degree was in Government and International Relations-she had five subfields including Geography, American History, and European History. Hence, while her degree was in Politics and International Relations-she taught in Howard's history department where she specialized in Diplomatic History. See Tate's CV and biographical papers, Tate Papers, box 219, folder 2, Manuscript Division, Moorland-Spingarn Research Center, Howard University, Washington, DC. 
relations of a more scholarly character than mine and has two others in the field of geopolitics in preparation, then I should feel that their application should by all means take precedence over mine." 33

Tate had training and expertise in five subspecialties-geography, history, economics, sociology, and government. She taught in all of these areas at some point in her career and while she did not get the position in geography, she was offered a position in the History Department. Rayford Logan endorsed his support for Tate as a permanent faculty member with a strong letter of support to J. St. Clair Price, Dean of the College of Liberal Arts and invited her to join the History Department. He wrote in part:

I wish to recommend in the strongest possible terms the permanent appoint-
ment of Dr. Merze Tate in the Department of History with the rank and
salary that she is willing to accept. Dr. Tate's caliber of work during the past
three years has been so high that comment is unnecessary. During my leave
of absence she has acted just as ably as head of the Department. ${ }^{34}$

Tate was offered a tenure track position in history and became a full professor in 1946. In the beginning, Logan and Tate had a positive working relationship and he respected and admired her talents. His enthusiastic letter of recommendation for her to be hired reflected this. He noted in a journal entry in 1947 that a conference that had been sponsored by the history department on "Trust and Non-SelfGoverning Territories" had been quite successful and commented that "Merze Tate did her thorough job of getting the speakers." ${ }^{35}$ Later that year, Logan noted in his diary, "Dr. Tate made some valuable suggestions as to the style for 'The African Mandates," a publication he was working on. ${ }^{36}$ When Logan was offered the opportunity for a scholarship to a one-week institute on the history of the United States and had a conflict and could not attend the sessions, he recommended Merze Tate be given the opportunity and scholarship as his replacement. ${ }^{37}$ However, the relationship soon soured as Tate began to realize that she was not treated with the same respect and payment as male faculty. She blamed Logan, as her department chair for her inequitable treatment.

\footnotetext{
${ }^{33}$ Ibid.

${ }^{34}$ Rayford Logan to J. St. Clair Price, Dean of the College of Liberal Arts, Howard University, June 6, 1945, Tate Papers, box 219-5, folder 29, Manuscript Division, Moorland-Spingarn Research Center, Howard University, Washington, DC.

${ }^{35}$ Diary Entry, April 12, 1947, Logan Papers, box 4, folder 4.

${ }^{36}$ Diary Entry, August 30, 1947, Logan Papers, box 4, folder 4.

${ }^{37}$ Rayford Logan to Ruth Lawson, Mount Holyoke College Institute on the UN, May 26, 1949, Rayford Logan Papers, Manuscript Division, Moorland-Spingarn Research Center, Howard University, Washington, DC.
} 
As will be discussed in detail below, by the early 1950s, their relationship deteriorated and became one of continuous battles and accusations of professional and psychological abuse of one another. ${ }^{38}$

Tate was on sabbatical, the academic year of 1950-1951, in India on a Fulbright Lectureship and Logan was on leave and out of the country the following year, 1951-1952. Upon returning home in fall of 1951, Tate, due to Logan's absence, was appointed as interim head of the history department without her knowledge. When she discovered this unwanted appointment, she was outraged and contacted the Dean of Liberal Arts to express her protest. Noting her shock at the learning of this assignment, Tate wrote, "my approval of the appointment had not been sought and I had not been given previous warning. I refused the announced assignment but was told that I had to do the work." She stated, "I have never wanted the administrative headaches attached to the department and much prefer to teach regular classes twelve or fifteen hours per week. Twice the work has been forced on me against my will and without adequate office and secretarial space." 39

Tate then discussed the salary inequities at the University. She stated it would be logical if she were expected to do extra work that she should obtain extra pay. She asked, "Why should I be expected to do the extra work on a salary of $\$ 6,030$ when another member of the department, free from all administrative problems, is to receive $\$ 6,250$ - or $\$ 220$ more than the acting head, and still a third member is paid $\$ 5,080$, just $\$ 50$ less-and has absolutely no responsibilities or burdens and does not even teach or supervise graduate students?" She ended the letter with the ultimatum, "unless some adjustment to my salary is made and secretarial assistance provided, I shall not be able to continue in the present role." ${ }^{40}$ In addition to sending the letter to J. St. Clair Price, the Dean of the College of Liberal Arts, Tate sent a copy to William Stuart Nelson, Dean of the University.

It was clear that Tate was serious about her refusal to be used and under paid. St. Clair Price met with her to discuss her salary. After their meeting, Tate wrote a very detailed and pointed letter to Price on October 29, 1951, regarding her compensation at Howard. She stated she wanted to put her sentiments in writing so that there would be a written record and no "misunderstanding, delay, or circumvention."

\footnotetext{
${ }^{38}$ Both Logan's diaries and Tate's Papers have continuous documentation of their ongoing professional and personal battles.

${ }^{39}$ Merze Tate to J. St. Clair Price, Dean of the College of Liberal Arts, October 4, 1951, Tate Papers, Manuscript Division, Moorland-Spingarn Research Center, Howard University, Washington, DC.

${ }^{40}$ Merze Tate to William Stuart Nelson and J. St. Clair Price, October 4, 1951, Tate Papers, box 219-5, folder 29, Manuscript Division, Moorland-Spingarn Research Center, Howard University, Washington, DC.
} 
She told him, "stated briefly, my position is that I shall not quietly accept a status and a salary in the department inferior to that of any other member, except the chairman." She noted in great detail her academic qualifications and achievements.

If remuneration is based upon academic preparation, honors, degrees, experience, publications, travel, prestige, and the publicity and glory a professor brings to Howard University and not upon personal, fraternal, and differences-in-sex consideration, than I stand second to none of the regular members, and in some instances surpass the head of the department. ${ }^{41}$

Tate outlined the highly prestigious universities that she had attended, her membership in two highly prestigious honor societies, her publications, honors, administrative work, the many fields that she was qualified to teach in and the fact that she had to teach twenty-five different classes in the years she had taught at Howard. She said:

No other member has been requested to teach in so many different fields or
has been assigned such a variety of subjects, including European, English,
American, Diplomatic, and Military History, International Politics, Political
Science, Geography, and Geopolitics. Other members of the department
teach only in one field. ${ }^{42}$

Her letter continued that she was forced to teach a course in the middle of the semester when a professor could not handle a course in Geography. She said she had to do this to save a contract the University had with the Army to offer the course. "This necessitated my carrying double sections of seventy men in one class." She said when the program was in full swing and the classes now had only eight to twelve students and could be taught with ease, the course was denied to her and given to another professor. ${ }^{43}$ Tate noted her extensive world travel, her teaching abroad, her work with UNESCO and the State Department. She said she regretted having to outline her qualifications to administrators. She said she realized they expected her to have a "saintly approach and accept silently and supinely an inferior status and salary and still carry the heaviest burdens." But, she informed him, if Howard University were in financial straits,

${ }^{41}$ Tate to J. St. Clair Price, October 29, 1951, Tate Papers, box 219-5, folder 29, Manuscript Division, Moorland-Spingarn Research Center, Howard University, Washington, DC.

${ }^{42}$ Tate to J. St. Clair Price, Tate Papers, box 219-5, folder 29, Manuscript Division, Moorland-Spingarn Research Center, Howard University, Washington, DC.

${ }^{43}$ Tate to J. St. Clair Price, October 29, 1951, Tate Papers, Manuscript Division, Moorland-Spingarn Research Center, Howard University, Washington, DC. 
I for the sake of the University and our youth - should be willing to teach without complaint. But, the University does have money, and apparently salary increases are based upon pressure, personal, and difference-in-sex considerations.

Tate noted there was a pattern in the history department of paying women faculty less than men. "Yet the cost of living for a single woman is greater than that of a married man whose spouse is employed." 44 Tate made it very clear that she was not the grateful, self-sacrificing woman who valued service over compensation when it was clear that Howard had the funds to pay her. In closing, Tate wrote:

Therefore, I trust you will consider my case in its true light and adjust my salary accordingly. This is an important and urgent matter, for with a ten percent increase pending, the supplement should be based on the proper adjusted salary. For me to accept an inferior status and salary would be a quiet recognition of incompetence and inferiority or evidence of inability to protect my own interests.

She asked for a response in writing. She copied President Mordecai Johnson, William Stuart Nelson, Dean of the University, and Charles H. Thompson, Dean of the Graduate School. ${ }^{45}$

\section{The Faculty Wives Club and the Women's Faculty Club}

Tate got her salary increase. After this incident, and as a result of the mounting dissatisfaction of the mistreatment of women faculty, a group of black women faculty who was members of the Women's Faculty Club (WFC) established a special committee of the group on the Committee on the Status of Women at Howard. The WFC was established in 1940 prior to Tate's arrival at Howard due to the growing number of women faculty. The records of this group are sparse. However, Tate's Papers include programs, newsletters, and the constitution of the group. The organization had a broad membership and was opened to: all women faculty in all Schools, professional library staff, the dean of women, educational directors of the women's dormitories, the dietitian, the household manager, women physicians, and the nurses in charge of women students. ${ }^{46}$ According to their constitution, their primary purpose was "to promote closer fellowship among the professional women

\footnotetext{
${ }^{44}$ Tate to J. St. Clair Price, October 29, 1951,Tate Papers, Manuscript Division, Moorland-Spingarn Research Center, Howard University, Washington, DC.

${ }^{45}$ Ibid.

${ }^{46}$ Constitution of the Women's Faculty Club, March 1953, Tate Papers, box 219-17, folder 20, Manuscript Division, Moorland-Spingarn Research Center, Howard University, Washington, DC.
} 
of the University, to form national and international culture and to assist the students of the University in whatever ways may be necessary." 47 This group was established two years after the founding of the Faculty Wives Club in 1938 (FWC). This organization was started by Sue Bailey Thurman, a Spelman and Oberlin College graduate who had worked with the National Young Women's Christian Association (YWCA) and was the wife of theologian Howard Thurman, who was the first Dean of Howard University's Chapel (1932-1944). The organization's history stated that the wives of Howard faculty had felt for years that there was a need for an organization for them for friendship and social relations. It noted that since many of the wives were not from Washington, DC, this group would provide them the opportunity to band together to assist students at Howard and for cultural events. The membership included the wives of faculty from all of these various Schools of Howard University. The president of the University's wife was always the honorary president of the group. Throughout the years, the group provided loans to Howard students, sponsored numerous cultural events-concerts, lectures, dramatic performances, etc. Dorothy Porter, who was chief librarian at Howard, was a member of both the FWC and the Female Faculty Club. ${ }^{48}$

Both groups appeared very active and had some overlapping yet different goals. Both sought to establish fellowship and mutual friendship with other women of their groups. However, the Female Faculty Club (FFC) was organized primarily for professional reasons since there were many other social, civic, and Greek letter organizations to affiliate with in DC. The FFC's newsletters reflected that they kept records of the women's faculty accomplishments-degree attainments, publications, fellowships and awards, sabbatical leaves, promotions, new hires. ${ }^{49}$ Meetings were held monthly both at various members' homes as well as at the University. According to their records, the group had

${ }^{47}$ Ibid.

${ }^{48}$ Mrs. G. Frederick Stanton, "Howard University Faculty Club: A Brief History," Faculty Wives Club Papers, folder 1, Manuscript Division, Moorland-Spingarn Research Center, Howard University, Washington, DC.

${ }^{49}$ For example, the October 1951 newsletter noted that Dr. Tate had been a Fulbright Fellow and had lectured in India and the Far East, Dr. Flemmie Kittrell also had a Fulbright award and spent a year in India organizing a Division of Home Economics for a college there; Dr. Anne Cooke of the theater department also received a Fulbright to spend the year of 1951-1952 at the University of Oslo. Another woman, Vera Hunton, received her doctorate at McGill University. There were other announcements highlighting milestones in their careers. Women's Faculty Newsletter, October 1951, Tate Papers, Manuscript Division, Moorland-Spingarn Research Center, Howard University, Washington, DC. 
luncheon and evening meetings. ${ }^{50}$ The newsletter indicated that Anna Johnson, wife of President Johnson, was also the honorary president of this group as well as the FWC and hosted their meetings in her home as well. ${ }^{51}$ Since Mrs. Johnson was neither faculty, staff, nor administrator, her membership was obviously honorary. Mrs. Johnson was known as a demure nonfeminist spouse who was active in "cultured" events. Having the president's wife close to the women faculty and aware of their concerns and interests was very strategic of the women of the WFC. ${ }^{52}$ The organization held an annual vesper in appreciation and recognition of women who had served or were serving at Howard from its founding until the present. President Mordecai Johnson always gave the message, while the president of the group gave remarks. On notes Tate wrote on the back of her 1949 program, she indicated that the speaker, Dr. Ruth Ella Moore, president of the WFC, remarked that more than half of all employees at Howard were women. Three of the members of the Board of Trustees were women; the Director of the Health Services was a woman (Dr. Ferebee); there were key women who worked in the Budget Office in Payroll and Bookkeeping; there were women students in every school, including Engineering and Architecture; and women were on the faculty of all schools except the Schools of Engineering and Architecture. Despite these seemingly positive data, the WFC members had aspiration of becoming a chapter of the American Association of University Women (AAUW). AAUW, the major organization of college-educated women, required each institution applying for a chapter to submit a list of all women on the faculty and their ranks, a list of all women administrators, the list of women in policy-making positions, and the position and role of the woman serving as Dean of Women and her authority and relationship to the president. In addition to these data, the committee decided to ask President Johnson to authorize deans to provide them with salary data of each school by gender breakdown. Also, they requested the length of time in rank for every faculty member. ${ }^{53} \mathrm{He}$ agreed.

${ }^{50}$ The Women's Faculty Club of Howard University's Newsletter, Tate Papers, box 219-7, folder 20, Manuscript Division, Moorland-Spingarn Research Center, Howard University, Washington, DC.

${ }^{51}$ Ibid.

${ }^{52}$ When Anna Gardner Johnson died in 1969, her obituary in the prominent black newspaper, the Afro-American (Baltimore), praised her for knowing her place as a wife. She was praised for being a "quiet unassuming woman," who "faded into the background of her illustrious husband." "She took her place in women's affairs without being obtrusive. She did not try to be vice-president of Howard or a dynamic feminine leader. She played with dignity her role of a wife. No one could ask more of a woman than that." Afro-American (Baltimore), March 15, 1969, 5.

${ }^{53}$ Minutes of the Committee on AAUW Accreditation meeting, March 3, 1961, Tate Papers, Manuscript Division, Moorland-Spingarn Research Center, Howard University, Washington, DC. 
Merze Tate and Dorothy Ferebee were very active in the DC chapter of the AAUW. Tate stated that because of the inequitable treatment of women at Howard, they were not able to get the chapter. She stated that men were always given summer teaching positions to earn more money at the expense of women faculty. On this issue, Tate stated, "Women were out." 54 In addition, she stated the committee found that "we had salary scales for professors, associates, assistants and but the women were always at the lower level of the scale, seldom in the middle." 55 Tate was responsible for compiling the data for the women faculty in the College of Liberal Arts. Patricia Robert Harris prepared the data for the Law School where she was on the faculty and later Dean; Dorothy Ferebee was responsible for the data from the Medical School; Annette Eaton, Associate Professor of Classics, who later became Associate Dean of the School of Liberal Arts, compiled the data for women administrators; Gertrude Rivers of the English department compared the salaries of women department heads with those of male departments heads in the same categories. Someone also provided information on women in the Dental School (the name was not listed but the report is in the files). ${ }^{56}$ The FFC was chaired throughout the years by the most seniar women at Howard and those who had distinguished themselves in their fields and were often among the first to obtain doctorates in their fields. ${ }^{57}$

Although there were women faculty who were not black at Howard, it appears that the leadership and leading force of the Female Faculty Club were black women. This group compiled data by departments on salary, appointments, and rank by gender for years. The first report they released was for the academic year 1953-1954. The report noted there were seventy-three full-time male faculty members and thirtyone full-time female faculty members. Twenty-six of the men were full professors and only four women were full professors (of which Tate was one). There were twenty-two male associate professors and eight female associate professors, seven male assistant professors and three

${ }^{54}$ Tate in Ferebee's Oral History, Black Women Oral History Project, December 28 and 31, 1979, Radcliffe College, Cambridge, MA, 34.

${ }^{55} \mathrm{Ibid}$.

${ }^{56}$ Minutes of the Committee on AAUW Accreditation, March 28, 1961, Tate Papers, Manuscript Division, Moorland-Spingarn Research Center, Howard University, Washington, DC.

${ }^{57}$ For examples, presidents of the FFC included Dorothy Ferebee, MD, who in 1924 became the first Black woman to earn a medical degree from Tufts Medical School; Ruth Ella Moore, $\mathrm{PhD}$, who in 1933 first black women to earn a PhD in Bacteriology from The Ohio State University, joined the faculty at Howard in 1941; Gertrude B. Rivers, who received a PhD in English from Cornell in 1939, also joined Howard's faculty in 1941; Inabel Lindsay, Dean of the School of Social Work. 
women assistant professors, eighteen male instructors and fourteen female instructors, and two female assistants (laboratories). ${ }^{58}$

The activities of the WFC overlapped with Tate's battles with Logan. In addition to Tate's crusade to expose Howard's inequitable pay and treatment of women, Tate waged an all-out war with Rayford Logan in the history department over course scheduling, the lack of secretarial assistance (for the typing of her manuscripts and other slights), and summer school teaching opportunities. Logan had assigned Tate a course to meet on Tuesdays, Thursdays, and Saturday and Tate attempted to reschedule the Saturday class to another time with the approval of the students. Logan repeatedly wrote letters to Tate to put on the record that she had not met her Saturday class. The first conflict arose in 1954 and continued over the course of years with Tate ignoring Logan until Logan finally contacted the Dean of the College regarding the matter. ${ }^{59}$

The administration rarely, if ever, reprimanded Tate for Logan's endless complaints and letters about her (which Logan deeply resented). From the existing records, it appears that most of the administration believed Logan had an obsession with Tate. She was well liked by members of the administration and she maintained cordial and social relationships with the wives of many of the male administrators. Tate was well connected through her work in international relations and she also served as a consultant to the Department of State, where she served as a military escort around the world. She knew ambassadors and other high-ranking international officials and was also highly thought of in the Radcliffe-Harvard communities. Tate was given the Distinguished Alumnae Award from Radcliffe College in 1953 and from 1953 to 1958; Tate served as Vice President of the Radcliffe Club of Washington, DC. These accomplishments resulted in Tate being highly prestigious not only for Tate, but for Howard as well.

Logan began to refer to Tate as "the bitch" in his diary. When Tate criticized Logan in a faculty meeting in the fall of 1954 for not being forceful enough in attempting to get supplies for the history department (implying he was weak), he wrote in his diary, "She was yapping, 'look at the equipment that the physics department has, no wonder there is no respect for the history department." "I walked away from her because I have stood all the abuse I am going to stand from the damn bitch. She is insufferable." 60

58"Report of the Status of Faculty in College of Liberal Arts by Department, Rank and Sex with Number of Rank and Salary, 1953-54." In possession of author, sent by Merze Tate, November 1987.

${ }^{59}$ See folder 14 in the Logan Papers for the repeated correspondence on this issue.

${ }^{60}$ Untitled, September 23, 1954, Logan Papers. 
Tate continued to push for a higher salary. Despite the increases she continued to receive, they never matched those of her male peers. She monitored salaries and ensured that no male faculty within her department (other than Logan) earned more than she did. In a 1956 letter to William Stuart Nelson, Dean of the University, she repeated to him that her qualifications exceeded the male faculty. Both Logan as Chair and John Hope Franklin earned more than she did. Nelson responded that salary increases are based on recommendations from the Dean of her College and she should communicate with him about this situation. ${ }^{61}$

Rayford Logan, who served as chair of the History Department at Howard until 1964, refuted Tate's charges of sexism in his diary. Tate was convinced that she was treated differently because of her gender. She confronted Logan in a faculty meeting in 1954 about summer school appointments. She told Logan pointedly that she felt he showed favoritism to male faculty members. She said she and another woman faculty member, Marie Wood, had been assigned only one course each instead of two like the men. Logan wrote long diary entries concerning the matter and noted: "I tried, in vain, to point out that there was no discrimination against her because of her sex. I said that such an idea was 'silly.' Still, she insisted that he had been unfair to her, had violated our agreement [to assign summer school appointments on a rotating basis] and he had done so because she was a woman." Logan also pointed out that classes were assigned based on need. Tate stated that her graduatelevel course on American Diplomatic History had not been assigned. He stated,

I pointed out that she knew as well as the rest of us did that the department had decided as a matter of policy not to offer any graduate courses in the Summer School since the Summer School policy insisted upon a minimum number of students. If not, the professor would only earn fees and not a full salary. This would not make it worthwhile for a professor to offer a course. ${ }^{62}$

Tate then said she would teach the American History course, which Logan had said had priority. One of the male professors commented that Tate was not qualified to teach the course. In response to this statement, Tate exploded. In tears, she stated that she studied and received her degree from the same institution as Logan and John Hope Franklin (Harvard University). She said she had studied with the same

${ }^{61}$ Tate to Stuart Nelson, October 16, 1956; Stuart Nelson to Tate, October 31, 1956, Tate Papers, box 219-4, folder 17, Manuscript Division, Moorland-Spingarn Research Center, Howard University, Washington, DC.

${ }^{62}$ Tate in Dorothy Bounding Ferebee, December 28 and 31, Black Women Oral History Project, Radcliffe College, 34. 
professors, had been examined in five subjects, including American History. According to Logan's diary, although he says he did not hear the comment, several people reported that Tate then said, if anyone said again she was not competent to teach American History she would bring in her gun and shoot them. ${ }^{63}$

As unbelievable as the above episode was, it is clear that Tate was provoked to the point of outrage. When persons who had been at the meeting told this event again to Logan the next day, he decided to report the incident to the Dean of Liberal Arts, J. St. Claire Price. He rushed to Price's office the same day. Price was not in for the day but Logan reported the story to the Assistant Dean, Carroll Miller. While Miller was obviously shocked by the story, he did not appear alarmed or concerned that this was anything but an unfortunate outburst. Logan said he told Miller he found Tate "intolerable" and wanted her moved out of his office (they shared an office). He said that Tate had been rude to people who called him on the phone, informing them that she did not know where he was and refused to take messages, telling the callers that she was not his secretary. In an attempt to stall Logan, Miller asked him to wait until the holidays to find another place to house her. ${ }^{64}$

Logan consulted John Hope Franklin about sending the letter. Franklin told Logan he was against him sending the letter. He said it would only make matters worse. According to Logan's diary, Franklin told him that Tate would simply go to President Johnson and members of the Board of Trustees. Logan stated although he normally followed Franklin's advice, he decided to send the letter with a copy to Tate. Franklin told him if he insisted on sending the letter that he wished Logan would delete the last paragraph (in which he called Tate intolerable and wanted her out of his office). ${ }^{65}$

Three days after the history department meeting, Logan wrote an official letter to Price about Tate. It read:

At a meeting in my office on December 8, 1954 for the purpose of discussing preliminary plans for summer school, Professor Merze Tate said in effect and almost verbatim that if any member of the Department should say again that she was not competent to teach a particular course in American History, she would get a pistol and shoot him. She added that she meant what she had said. Present at the meeting were Professor Logan, Franklin and Tate, associate Professors Hansberry and Lofton; Mrs. Tucker. While I have little fear that Professor Tate will carry out her threat, I am reporting it to you for such action as you deem appropriate. ${ }^{66}$

\footnotetext{
${ }^{63}$ Diary entry, December 9, 1954, Logan Papers, box 6, folder 1.

${ }^{64}$ Diary entry, December 9, 1954, Logan Papers.

${ }^{65}$ Diary entry, December 11, 1954, Logan Papers.

${ }^{66}$ Letter, December 11, 1954, Logan Papers.
} 
Logan believed this was the incident that would succeed in ousting Tate not only from her office in the History Department but from Howard University as well. However, Tate had many friends in the central administration. Most of the male administrators viewed Logan as irrationally obsessed with Tate and constantly told him to not overreact. Logan did not seem to get the message. By the late 1950s, and particularly after this attempt of Logan to oust Tate, the senior administrators grew weary of Logan's complaints regarding her. He kept records of very minor instances as well as those he thought major and repeatedly wrote memos to the administration about her. He noted in his diary in 1957: "Snowden, Thompson and Nelson told him that he was 'persecuting' Tate." They stopped allowing Logan to make appointments with them to discuss Tate and referred him to their assistants and secretaries. ${ }^{67}$ Franklin and his wife maintained a warm friendship with Tate and as he noted, Tate also had a very warm relationship with President Johnson and his wife as well as many of the male administrators in the central administration and she knew many of the trustees. In addition, as noted earlier, Tate was friends and attended social events with many of their wives.

Tate was able to delay her move from Logan's office until April of the next year. ${ }^{68}$ Logan and Franklin were Tate's professional peers in terms of rank and also productivity. All three were Phi Beta Kappa key holders and had doctorates from Harvard University. Logan and Franklin were better known because of their work related to black history and civil rights. Tate's research was not focused on race and according to former colleagues and students of Tate's, most people did not realize she was an African American woman because of her research topics and the publication of her books in major academic presses. Her research concentrated on European diplomatic history, disarmament, advanced economics and world trade, international relations, and international law. Her first book was published the year after she received her doctorate entitled The Disarmament Illusion: The Movement for a Limitation of Armaments to 1907 (Macmillan, 1942). Harvard University Press published her second book, The United States and Armaments, in 1948. The U.S. State Department selected Tate as one of three persons chosen to represent the nation at a UNESCO conference in

${ }^{67}$ Diary entry, November 28, 1957, Logan Papers; others also believed Logan had an unhealthy obsession with Tate. His department secretary told him that John Hope Franklin was worried about him. She noted that Franklin was "fond of him" but was concerned about Logan's treatment of Tate. She said that Dr. Franklin told her that Tate was experiencing family problems--her sister-in-law had just lost a hand and that her sister had breast cancer. Diary entry, August 25, 1956, Logan Papers, box 6, folder 4.

${ }^{68}$ Untitled, May 13, 1955, Logan Papers. 
1948. Tate's books were enormously influential and were utilized by the U.S. Department of State and were required texts in international relations courses, international law, and diplomatic history at leading institutions, including Harvard, Yale, Princeton, American University, the University of Pennsylvania, and the University of Michigan. Tate published three additional books, one in 1965 published by Yale Press, another in 1968 published by Michigan State University Press, and one in 1973 from Howard University Press. Tate published constantly beginning with journal articles and monographs from 1937 to $1980 .^{69}$ When she retired, her annual report reflected that, in addition to her books, she had published over sixty journal articles and had received many academic fellowships and awards.

\section{Mordecai Johnson}

Tate's relationship with Mordecai Johnson was a curious one. While Johnson had a very Jekyll and Hyde personality, Tate viewed him as a trusted supporter. Logan hated Johnson and his diaries are full of as many negative comments and rants about him as there are about Tate. His dislike for both of them was so great that when he was in the hospital and thought he may die of a heart attack he wrote a letter to two of his closest friends with instructions that if he died he did not want either Johnson or Tate "to have anything to say at my funeral or to participate in any way." 70

While Johnson is well known for developing Howard into the "capstone" of black higher education, he also had a reputation for his many controversies, disagreements, and disputes with Howard faculty, staff, and alumni. While Johnson was, without question, misogynistic and sexist, he had many confrontations with male administrators and faculty as well. It was clear that the issue with him was power and control. ${ }^{71}$

Inabeth Burns Lindsay was a Howard alumna who served on the faculty for decades. Lindsay graduated from Howard in 1920 with honors and was awarded an Urban League Fellowship to attend the New

${ }^{69}$ For a bibliography of Tate's work, see Joseph Harris's "Professor Merze Tate (1905-): A Profile," in Profiles, The Graduate School of Arts and Sciences, Howard University, Washington, DC, December 1981, 23-24.

${ }^{70}$ Diary entry, December 21, 1956, Logan Papers.

${ }^{71}$ For lengthy discussions of Johnson's battles with various Howard faculty and administrators, see Logan's Howard University (particularly Logan's characterization of Johnson's “vendetta" against Emmett Scott, Secretary-Treasurer), p. 288; see also Kenneth R. Manning's biography of renown biologist Ernest Just and his battles with Johnson, Black Apollo of Science: The Life of Ernest Everett fust (New York and Oxford: Oxford University Press, 1983); also see Williams, In Search of the Talented Tenth, his long list of Black male faculty and administrators with whom Johnson clashed, 63. 
York School of Social Work. After a year of study in New York, she returned home to St. Joseph, Missouri, to care for her ill mother. Since there were no social service agencies in her hometown, Lindsay taught public school for one year. She married by 1937, had earned a master's degree in Social Work from the University of Chicago School of Social Service Administration. She was then invited in 1941 to join the faculty at Howard to assist in establishing a School of Social Work (SSW). She was appointed Director of Program of Social Services. In 1944, the Howard University trustees voted to establish an autonomous SSW. In 1945, Lindsay was appointed the first Dean of the School. By 1952, she had earned a Doctorate in Social Work from the School of Social Work at the University of Pittsburgh. ${ }^{72}$

Lindsay, who was a good friend of Tate, and in several oral histories, was very candid concerning the status of women at Howard during the Johnson presidency and of her experiences on the campus. She confirmed Tate's observations about Howard University. Despite the many women faculty members at Howard and the appearance of egalitarianism, Lindsay stated women were usually paid less and were subjected to gender bias. She stated she became dean of the School of Social Work by default. She explained that Johnson wanted to appoint a qualified man for dean (she stated, "chauvinistically they wanted a male dean"). However, Johnson could not find a man to take the job because they could command higher salaries in the government and other private agencies and places such as the National Urban League. Lindsay stated during the search for a Dean, the Association of Schools of Social Work was evaluating the SSW for accreditation. Howard officials were alerted that the School could not become accredited with her as Acting Dean. Lindsay, with this news, stated she was immediately appointed as permanent Dean.

Despite the decades that Lindsay served as Dean of the School of Social Work, she noted that President Johnson was extremely paternalistic toward her and women faculty in general. She recalled that Johnson never referred to her as Dr. Lindsay, Dean Lindsay, Professor Lindsey, or even Mrs. Lindsay, but rather called her "daughter." She said she did not think he did this out of malice but rather "reflected the culture of which he was accustomed." $" 73$

Lindsay stated that Johnson, an ordained Baptist minister, had a conservative view of women and believed that women should be subordinate. Lindsay stated that she was the only woman on the Dean's Council for years. She also stated she was not expected to make any

\footnotetext{
${ }^{72}$ Interview with Inabel Burns Lindsay, May 20-June 7, 1977, Black Women's Oral History Project, Radcliffe College, Cambridge, MA, 24.

${ }^{73}$ Ibid.
} 
contributions or make any suggestions at these meetings. As a result, she found sexism a much greater barrier to her professional career than race:

I was in a predominately Negro institution, so that race was secondary. Sex, however, was not. There were women on the faculty, of course, many of them, very fine, outstanding ones who were recognized and accorded to a degree the same academic opportunities of promotion and tenure, although there again, I think the bias of sex operated for all women. They didn't get promoted as readily, nor to as high a rank as a man. But, when it came to administration - outside of Home Economics, Nursing or Physical Education, which, of course, had a woman head of the physical education department, women didn't move into the central administration of the University. ${ }^{74}$

When Logan was Interim Dean of the Graduate School in 1943, he served as Lindsay's supervisor when the School of Social Work was a Division of the Graduate School and attempting to earn accreditation. His diary entries are full of very favorable comments of Lindsay and they clearly had a collaborative and cordial relationship. One diary entry noted that in the course of the Division being upgraded to a School, the new federal Child Welfare Program offered Lindsay a position as consultant. Her salary would have been $\$ 3200$ and $\$ 3600$ with overtime. He noted her salary at Howard was just \$2500. Lindsay ended up remaining at Howard to ensure the success of the new School. Logan's diary entry also noted that he hired Lindsay as Dean "since President Johnson would not make available a salary that would be attractive to Ira Reid [the male first choice]." 75

Lindsay recalled, "the salary was low. There wasn't anybody [male] who was interested in sacrificing to that extent." As noted above, when it was clear the School of Social Work could not become accredited without a permanent dean, Lindsay said, "the university administration very promptly changed my title to dean. I became the dean by happenstance." "76 As will be discussed later, as Lindsay noted, Johnson's attitudes merely reflected the views of most men of his era.

Women faculty at Howard did not universally dislike Mordecai Johnson. Dorothy Boulding Ferebee earned an MD from Tufts University School of Medicine in 1924. After completing her internship and clinical training in 1927, she was appointed to the Howard University Medical faculty in the department of Obstetrics. By 1929, she

\footnotetext{
${ }^{74}$ Ibid.

${ }^{75}$ Diary entry, March 4, 1943, Logan Papers, box 4, folder 2, Library of Congress, Washington, DC.

${ }^{76}$ Diary entry, October 22, 1954, Logan Papers, box 6, folder 1.
} 
was appointed to head the University Medical Center. She remained at Howard's Medical School for over forty years until retiring in 1968. Dr. Ferebee stated that while many male physicians at the Howard Medical School resented her position at the University, she stated she found an ally in Mordecai Johnson. She noted:

I think that sexism [at Howard] was a very common practice, and still is ...
I think that, even though I experienced discrimination and a great deal of
jealousy on the part of many of the men physicians and the men directors,
I had a staunch ally at Howard University in the person of Dr. Mordecai
Johnson, the president. He was absolutely superb in seeing that both men
and women whose qualifications were recognizable received the kind of
recognition to which they were entitled. So that for a long time, my serve
as medical director of Howard University Health Service largely was due
to Dr. Mordecai Johnson's approval of me, and the fact that the physicians
who were opposing me were a subterranean faction, were never able to
reach me because of the citations and recognition given me by the university
president.

Like Dr. Ferebee, Tate definitely saw Johnson as an ally and supporter. She contacted him repeatedly throughout her years at Howard concerning her conflicts with Logan and the salary inequities and her papers reflect cordial exchanges with him and numerous congratulations to her from him regarding her many scholarly accomplishments. ${ }^{78}$ As noted, Johnson and Logan had a very acrimonious relationship that had nothing to do with Tate.

In a 1993 oral history, Dorothy Porter Wesley, who was also a graduate of Howard and a member of the library staff for more than forty years (1932-1975), commented on her life at Howard and confirmed Tate's assessment. Like Slowe, Lindsay, Ferebee, and Tate, Wesley recalled her experience at Howard as being discriminatory to women. She stated:

At Howard at one time it was a completely a male situation, and they Didn't think even the Dean of the School of Social Work (Inabel Burns Lindsay)

${ }^{77}$ Dorothy Boulding Ferebee, Interview with Radcliffe College, December 28 and 31, 1979, 34 in Women of Courage Collection, Radcliffe Black Women's Oral History Project, Schlesinger Library, Radcliffe College, Cambridge, MA.

${ }^{78}$ In one of Logan's many complaints about Tate in his diary, he commented on a luncheon Tate sponsored on behalf of the Radcliffe College Club that President Johnson attended. Logan wrote in annoyance: "President Johnson spent fifteen minutes praising Merze Tate" and called her "one of the world's greatest historians." The guests at the luncheon included ambassadors and other renowned guests. May 3, 1956, Logan Papers, Library of Congress. 
amounted to anything. The dean of students-the woman dean-had to go to the dean of men to get a roll of toilet paper sometimes. ${ }^{79}$

Wesley stated again that women were significantly underpaid. She recalled during the Johnson presidency, women's salaries were not equal to men in the same rank. She stated, "My salary was always low. I never made any money. I resigned a couple of times, but they [her administrative superiors and friends] made me go back." 80

As noted, the views of Johnson by many of the women were varied. Nevertheless, women faculty was discriminated in rank and salary from male faculty. ${ }^{81}$ While the issues of the men (Logan included) who disliked and had conflicts with Johnson appeared to reflect male ego and power dynamics, the issues with women faculty appeared to be boiled down to paternalism and sexism.

In 1977, Tate interviewed Eva Dykes for the Radcliffe Black Women's Oral History project. Dykes was one of the first three black women to earn a PhD in 1921. She noted that Mordecai Johnson hired her after she earned her doctorate from Radcliffe. Dykes taught in the Department of English at Howard from 1929 to 1944 and was awarded the best faculty member in the College of Liberal Arts during her tenure there. When Dykes became a member of the Seventh Day Adventist Church, she left Howard to teach at the all-Black Seven Day Adventist Oakwood College in Alabama. During the interview, Tate asked Dykes about sexism in her career. She asked, "Do you think your sex has had anything to do with your status in various places? Do you think if you'd been a man, with a Harvard degree, you might have had higher salary at Howard University?" Dykes said she did not concentrate on salaries at that time. Tate told Dykes about the study of salary discrimination she did at Howard. Tate told Dykes:

It was so vicious-Mordecai Johnson asked me to do it-that he was shocked, I mean statistically. But sometimes they wouldn't even give me the figures I needed. But even those that I got-and some changes were made as a palliative. And then at different times some deans have tried to be a little more just, but men were always at the top....82

Dykes noted that she just saw sexism and salary discrimination as a fact of life. She said she was not driven by money. She noted the

${ }^{79}$ Transcript of an oral history interview of Dorothy Burnett Porter Wesley, January 28 and February 10, 1993, Howard University Oral Histories, Manuscript Division, Moorland-Spingarn Library, Howard University, Washington, DC.

${ }^{80}$ Ibid.

${ }^{81}$ Ibid.

${ }^{82}$ Interview with Eva Dykes, Black Women's Oral History Project, November 30December 1, 1977, 30-31. 
current efforts of "women's lib and other women groups" and said, "I've tried to be satisfied, because my main interest isn't money. I've tried to be pleased" and commented she was not bitter or rebellious about being a woman. She told Tate that she had heard that there had been recent promotions and salary increases to the faculty at Oakwood. She noted that when she saw the president and asked him why she did not get a salary increase, he told her, "you're a woman, that's why." 83 She reflected that if she went to the grocery store, she would have to pay the same price as a man for goods. Yet, she did not protest the oversight or the blatant sexist remark. Of course, this response stunned Tate. She xeroxed these pages of the interview with Dykes to the author as an example of a woman who never challenged discrimination. ${ }^{84}$ As reflected by Dykes's response, she viewed sexism and lesser pay as a fact of life and not something she cared to protest.

\title{
Howard University, Post-Mordecai Johnson
}

After Mordecai Johnson retired in 1960 and James Nabrit, a civil rights attorney, was appointed to replace him, Tate immediately wrote Nabrit a letter of congratulations and stated among other things:

\begin{abstract}
Since you have carved a distinguished place for yourself in the field of Civil Rights, I trust some of your legalistic talent will be directed toward equating Howard University salaries with those of federal and DC Teachers College employees and that you will also take cognizance of the discriminatory treatment of women faculty members. It is this clearly recognized discrimination in various forms, which over the years has prevented Howard University from being accepted in to the American Association of University Women. Your esteemed predecessor made serious efforts to remedy this situation and was extremely anxious for the University to have a chapter of the AAUW, but the inequitable treatment stemming from the policies of some men heads of departments, tolerated by the deans of the College of Liberal Arts, apparently could or would not be overcome. You, I trust, will be more successful along this line. ${ }^{85}$
\end{abstract}

Why Tate believed Mordecai Johnson was powerless to have equitable salaries among the women faculty is puzzling. Johnson was known to be a heavy-handed leader and if this was an issue he cared deeply about, it could have been remedied. Clearly the Deans who reported to

\footnotetext{
${ }^{83}$ Ibid., 31.

${ }^{84}$ Pages of interview of Tate with Dykes received by author via U.S. mail in November 1987.

${ }^{85}$ Merze Tate to President James Nabritt, no date, Tate Papers, box 219-5, folder 16, Manuscript Division, Moorland-Spingarn Research Center, Howard University, Washington, DC.
} 
him were not more powerful than Johnson. However, the Dean of the University always told Tate there was a "process" and that salaries were based on performance reviews and recommendations of the department chairs to the Deans of the respective Colleges. The appearance was given that the hands of the senior administrators were tied.

\section{Logan's Final Years at Howard}

By March of 1964, worn down from his years of battling with Tate and the Howard administration, Rayford Logan abruptly resigned as head of the History Department. In his diary, he noted that his decision was final and "irrevocable." He attributed his defeat in his dealing with Tate and his need for time to write the history of Howard (which he was commissioned to do for the University's centennial anniversary in 1967). Logan wrote a five-page letter of resignation and submitted it to the Dean. He asked why Logan did not wait until the end of the academic year to resign, and Logan responded: "I was not going to be bothered with Tate anymore." 86 He retired from the faculty in 1966. Tate had won the battle.

Logan's biographer, Kenneth Janken, described Logan as "supersensitive," "brutal," "prickly," and one who could turn a misunderstanding into a major incident and who used his power as chair to determine whose work was typed by secretaries, whose office supplies were ordered, and who received telephone lines in their offices-all concerns that Tate reported. Surprisingly, despite the evidence, Janken never mentions Tate's name or acknowledges Logan's horrible treatment of her in Logan's biography. Janken also noted Logan's insecurities about his academic stature compared to other notable Howard professors (Janken stated Logan was referred to as an academic "lightweight" by political scientist Ralph Bunche, sociologist E. Franklin Frazier, and economist Abram Harris, known as the "triumvirate" when Logan arrived at Howard). According to Janken, the three men were unenthusiastic about Logan's hire and excluded him from their social gatherings. Their dislike of Logan was based on philosophical and political disagreements. The three men viewed Logan as too fixated on race while they focused on issues of class. Logan referred to them as the "Marxist clique." 87

In addition to these insecurities about his stature among the prominent male faculty, Logan was professionally jealous of Tate. His diaries are full of jealous references to Tate's activities-particularly her being well respected and close to the Radcliffe (Harvard) professors and

${ }^{86}$ Diary entry, March 14, 1964, Logan Papers, box 6, folder 6.

${ }^{87}$ Ibid. 
deans. He resented her closeness to Mordecai Johnson and Johnson's high praise of Tate. In spite of all of the things Logan did to block Tate's professional growth, she was able to work around him. He was viewed as a historian of "Negro" history. In contrast, Tate's research was on disarmament and later on the Hawaiian Islands. She was very well published and as stated earlier, was a consultant for the State Department and traveled on their behalf globally. She was viewed as a historian of diplomatic and international studies. Logan commented on the fact that he believed Tate thought her work superior to his because it was not on "Negroes." 88 Also, Logan was not a social person and devoted himself to his scholarship, teaching, and writing. While he was very active in the Alpha Phi Alpha fraternity, the first black fraternity, by the late 1960s, he resigned from the organization due to their referral of themselves as a black fraternity, a term that Logan rejected. Janken notes that by the 1960s and particularly after his wife Ruth died in 1966, Logan became more eccentric and difficult and people avoided him. He became more isolated and alone. In contrast, Tate, who never married, was very socially active and her hobbies included cooking, photography, and world traveling. She was a champion bridge player, member of a writer's club of prominent academics and professionals in Washington, DC, and an active member of AKA, the WFC of Howard, as well as the Radcliffe Club of Washington, DC, and the DC chapter of the AAUW and other organizations. She had many friends and her papers are filled with thank you notes and cards to her for various social events she attended and/or sponsored. When it came to her problems with Logan, the administration was clearly in her corner. They did believe that she had been "persecuted" by Logan.

In April 1960, Stuart Nelson, the Dean of the University, called Logan in for a conference. Logan had no idea what the meeting was about. His diary noted that Nelson went straight to the point and asked him about the stories he had heard about Logan's negative treatment of Tate. Logan noted he was furious about the inquiry and said Stuart told him the meeting and discussion would be "off the record" and "unofficial." Stuart told Logan he was concerned about his "wear and tear" of himself over Tate. Logan repeated all of his grievances about Tate from over a decade and said he felt the administration "coddled and mollified" her and provided her with secretarial help (after he had denied her this request from the History Department). Nelson tried

\footnotetext{
${ }^{88}$ One of his diary entries noted that Tate asked him for some of his research to reference when she went on a Fulbright Fellowship to India. He stated one of the topics the Indians were interested in was the Negro in the United States. Logan noted he found this amusing since Tate always "sneered and belittled" research on Negro history. Diary entry, October 1, 1950, Logan Papers, box 5, folder 2.
} 
to gently let Logan know that the administration was concerned about not only his treatment of Tate but of his emotional and physical state as well. ${ }^{89}$

Logan's isolation and anger at his life at Howard wore on him. Furthermore, Logan, like most of the male faculty and administrators at Howard, lived in an era when although they may have been married to educated and accomplished women, most expected these women to subordinate themselves to them. Also, the fact that the "wives" of these men established an organization clearly indicated the fact that being married to these distinguished men was an important identifier to these women. Logan's wife Ruth was a college-educated, accomplished musician, and prior to her marriage to Logan was the director of the choir at Virginia State College and later established the music curriculum at Virginia Union College. After her marriage to Logan, he insisted that she abandon her career. They never had children. Ruth was expected to devote her life to Logan and he completely dominated her. His biographer noted:

... Logan rarely exchanged ideas with his wife; he separated his professional and personal lives in such a way to exclude her from the former. He restricted her intellectual and cultural growth to the ways he defined..$^{90}$

Janken also noted that when Ruth told Logan she desired to have a career, "Logan told her the penalty for such a choice would be the end of their marriage; he would not stand for his wife to have a career." 91 As was the case with most of these proud "race" men and their constant advocacy for racial equality, this view did not extend to women. Janken stated: “[Logan's] political positions did not transfer to his relations with women, for he had uneasy professional dealings with women. He held fast to traditional gender roles." 92 So, of course, he had problems with Tate, who did not show him the deference that he believed appropriate for women. Plus, she not only had a career but a spectacular career-one that rivaled Logan's.

But this was not an era when black men championed women's rights. With rare exceptions, regardless of their activism on race, like Logan, most embraced patriarchy. As early as 1890 , Anna Julia Cooper, Oberlin-educated black educator and feminist theorist, made this point in her book, $A$ Voice from the South: "... while our men seem thoroughly abreast of the times on almost every other subject, when they strike

\footnotetext{
${ }^{89}$ Logan, April 19, 1960, Logan Papers.

${ }^{90}$ Janken, Rayford W. Logan, 73.

${ }^{91}$ Ibid., 73.

${ }^{92}$ Ibid., 72.
} 
the woman question, they drop back into sixteenth century logic." 93 She also noted that black women were "confronted by both a woman question and a race problem, and as yet an unknown or unacknowledged factor in both." 94

In 1906, a conservative article in a black journal, expressed the prevailing view as more and more black women obtained college education:

\begin{abstract}
One thing the education of the Negro woman must not do, it must not educated her away from being a mother-it must not be an education that will make her feel that there is a higher sphere for women than that of being a mother ... the hope of the race is conditioned not upon the women on the platform, but upon the woman in the home-not upon the women whose highest ambition is to appear in public and pass resolutions about the race, but upon the mothers whose highest ambition is to not to show themselves and make public speeches, but whose highest ambition is to give the best there is in them to their children, women who find their chief joy not in being admired and talked and written about, but in loving and being loved by their children. ${ }^{95}$
\end{abstract}

These views impacted the women at Howard University. Dorothy Ferebee met her husband Claude Ferebee, who was on the faculty at the College of Dentistry at Howard. In 1930, they married and she subsequently had twins. Surprisingly, given the times and the customs, her pregnancy did not result in her dismissal for her job, or any expectation that she would leave. She noted, "I worked hard and regularly up until a month before the babies were expected, and did not give up my job for maternity leave until I was ready to go to the hospital."96 During this period, her husband was dismissed from Howard after a dispute with the Dean. Ferebee noted that after this incident, and also because of her success at Howard as well as in her private practice, she said he "insisted that I give up my work." She said, "of course, I wasn't going to do that." She said Claude Ferebee believed her position at Howard, as well as her successful medical practice, provided her more status and prestige than him. This was unthinkable to a man's ego at this time. Their marriage ended in divorce. ${ }^{97}$

\footnotetext{
${ }^{93}$ Anna Julia Cooper, $A$ Voice from the South (Xenia, OH: The Aldine Printing House, 1892), 134.

${ }^{94}$ Ibid.

${ }^{95}$ Thomas Nelson Baker, "The Negro Woman," Alexander's Magazine 2, no. 2, June $15,1906,84$.

${ }^{96}$ Dorothy Bouding Ferebee, Oral History, Radcliffe College, 28, December 31, 1979, in Women of Courage Collection, Radcliffe Oral History Project, Radcliffe College, Cambridge, MA, 35.

${ }^{97}$ Ibid.
} 
Inabeth Lindsay, who was also a very vocal and activist woman faculty member, also recalled that when she married Arnett Lindsay after obtaining her undergraduate degree in 1925, he expected her to be a stay-at-home wife. She said his view was the norm among black men by the 1920s. She said she complied the first year of their marriage but said:

I was quite bored, and guilty about not doing anything, because I said my mother worked too hard and spent too much money on my education for me not to be doing something with the education that was made possible. ${ }^{98}$

Lindsay not only convinced her husband that she should return to work but they had a commuting marriage for a period with her teaching at Howard University, while he taught at Clark College in Atlanta. ${ }^{99}$

As Lindsay noted, these women who obtained advanced degrees and invested time and money to obtain them were serious about their careers and making a contribution to the race. They did not view marriage as an end to their careers and thus went against the grain of the views of what was overwhelming viewed as a "good wife"-as was noted in the article in the Afro-American's which outlined Anna Johnson's virtues as President Johnson's wife.

Tate, along with Ferebee, Lindsay, and others were consistent voices at Howard on gender inequity at Howard. Far more vocal than black women faculty could be in other locations because of the lack of protection of tenure, these women were relentless in keeping women's issues before university administrators.

While the black women at Howard held the best jobs in black higher education because of the many benefits at Howard-tenure, sabbaticals, research leaves, the ability to do research and travel the world, and have graduate students; despite these important benefits, they knew that they were marginalized there. Sexism permeated across all the Schools of Howard's campus. Pauli Murray, who enrolled in the Law School in 1941 and subsequently became one of the founders of the National Organization for Women, noted that the Dean, Leon A. Ransom, recruited her. She noted her attraction to Howard's Law School because of its stellar faculty and its concentration on preparing Civil Rights attorneys. Murray stated that while she was aware of Jim Crow in society, her experience at Howard exposed her firsthand to "Jane Crow." She stated "the factor of gender was fully exposed."

\footnotetext{
${ }^{98}$ Anabeth Lindsay, oral history, Radcliffe College, 1978, 4.

${ }^{99}$ Ibid., 47; Commuting marriages among Black academics were not uncommon-see Linda M. Perkins, "For the Good of the Race: Married African American Academics: A Historical Perspective," in Academic Couples: Problems and Promises, ed. Marianne A. Ferber and Jane W. Loeb (Urbana, IL: University of Illinois Press, 1997), 80-105.
} 
She stated the male faculty was not hostile but actually friendly. She recalled sexist jokes made by male faculty at the expense of women. She was also excluded from "male smokers" given by the Law School to recruit members to a male legal fraternity. When Murray inquired about membership to this organization to Dean Ransom, she said she was shocked by him making a joke and advising her to start a legal sorority. She remembered:

The discovery that Ransom and other men I deeply admired because of their
dedication to civil rights, men who themselves had suffered racial indignities,
could countenance exclusion of women from their professional association
aroused an Incipient feminism in me long before I know the meaning of the
term "feminism." 100

However, as stated earlier, his view was the prevailing one-race oppression notwithstanding. At Ferebee's funeral on September 20, 1980, Patricia Roberts Harris, who served as the first woman Dean of Howard's Law School (1969), in her eulogy of Ferebee, stated:

Broad as her leadership was, how sad to think that the double handicap of race and sex shackled the talents and energies of this woman. I have often wondered what she could have done and where she might have led others had these leadership been accepted by our entire society earlier. Howard University, which has nurtured and maintained so many educated Black men and women, gave her a base from which to work (and even at Howard University, where race was not a factor, the virus of sexism limited her activity, a fact of which she was acutely aware). ${ }^{101}$

Tate, as well as the many other extraordinary women, highlighted in this article, were the most highly educated women of their race. Their gender experiences at Howard were not unique to women at HBCUs or society in general, but their documented vocal, organized, and passionate opposition to their treatment provides the greatest example of black feminism and intersectionality and adds to the scholarship on black feminism as well as the history of HBCUs. Tate received continuous recognition of her life of academic achievement. As early as 1963, she was awarded an honorary doctorate from Morgan State University in Baltimore, where she taught for one year from 1941 to 1942 . When she retired from Howard in 1977, she endowed the Merze Tate Seminar in Diplomatic History to continue her interest in her lifelong discipline.

${ }^{100}$ Pauli Murray, Song in a Weary Throat: An American Pilgrimage (New York, Harper and Row, 1987), 184.

${ }^{101}$ Eulogy of Dr. Dorothy Boulding Ferebee by Patricia Robert Harris, Secretary of Health and Human Services, September 20, 1980, Dorothy Ferebee, Manuscript Division, Moorland-Spingarn Research Center, Howard University, Washington, DC. 
She was awarded an honorary doctorate from Lincoln University in Pennsylvania in 1978, and in 1980, Radcliffe College Alumnae Association Graduate gave her the Distinguished Achievement Medal. In 1986, Howard University, the institution that she had devoted her life to, awarded her an honorary doctorate of Humane letters. Tate lived long enough for Howard to demonstrate their recognition of her thirtyfive years of devotion to the institution and her students. She died of cardiac arrest in 1996 at the age of $91 .^{102}$

${ }^{102}$ Merze Tate biographical sketch in the Merze Tate Papers Guide, Manuscript Division, Moorland-Spingarn Research Center, Howard University, Washington, DC. 